\title{
MENINGKATAN "COACHING SKILL" PELATIH BULUTANGKIS SUMATERA BARAT MELALUI PENDEKATAN BSDM (BADMINTON SKILL DIAGNOSIS MODEL) BERBASIS KINOVEA SOFTWARE
}

\author{
Donie $^{1}$, Yogi Setiawan ${ }^{2}$, Eval Edmizal ${ }^{3}$ \\ Universitas Negeri Padang $1,2,3,4,5,6,7$ \\ donie17@fik.unp.ac.id ${ }^{1}$, yogisetiawan@fik.unp.ac.id ${ }^{2}$, evaledmial@fik.unp.ac.id ${ }^{3}$
}

\begin{abstract}
Abstrak
Terkait dengan pembelajaran dan pelatihan cabang olahraga bulutangkis, dari observasi di lapangan ditemui beberapa klub pembinaan di Sumatera Barat ditemukan beberapa permasalahan mendasar, yakniMasih banyak pelatih belum memahami hakekat, fungsi dan tujuan dan cara memberikan koreksi terhadap kesalahan gerak atlet, Kebanyakan koreksi yang diberikan belum berdasarkan diagnosa yang tepat, Masih banyak pelatih belum memahami dengan baik analisis kesalahan gerak dan Kebanyakan koreksi gerakan yang diberikan berdasarkan pengamatan pelatih secara parsial, dengan kata lain koreksi yang diberikan mengabaikan dialog antara pelatih dan atlet.BSDM (Badminton Skill Diagnosis Model) merupakan sebuah temuan dalam mengevaluasi dengan menggunakan pendekatan situasional melalui Diagnosa, Koreksi, dan Terapi terhadap Kesalahan gerak yang terjadi, yang bertujuan untuk: Menentukan diagnosa kesalahan gerak yang terjadi, Melakukan koreksi atas kesalahan gerak yang terjadi dan memberikan terapi atas koreksi dari kesalahan gerak tersebut.Kinovea adalah pemutar video/visualyang telah dibuat khusus untuk para profesional olahraga dan pelatih. Pengguna dapat mengunggah video dari mereka yang mempraktikkan olahraga yang berbeda sehingga mereka dapat menganalisis gerakan olahragadan mendapatkan gambaran gerak yang dibutuhkan butuhkan untuk dianalisis, diperbaiki dan ditingkatkan performa gerak tersebutPenerapan teknologi BSDM berbasiskan kinovea software bagi pelatih dalam kegiatan evaluasi keterampilan teknik bermain bulutangkis akan keterampilan melatih (coaching Skill) khususnya dalam melakukan diagnosa, koreksi, dan perbaikan perbaikan yang lebih akurat dan tepat sasaran untuk memperbaiki keterampilan bermain bulutangkis secara keseluruhan. Kegiatan ini akan dikenalkan dan diterapkan pada seluruh pelatih bulutangkis Sumatera Barat yang mewakili dari masing masing utusan kabupaten kota dan klub-klub yang eksis dalam melakukan pembinaan sebanyak 40 orang. Pelaksanaan kegiatan dilaksanakan di Kota Padang karena sangat pesat pertumbuhan klub pembinaan dan memiliki fasilitas yang baik untuk melaksanakan kegiatan tersebut. Kegiatan ini merupakan kerjasama dengan mitra terkait yaitu PBSI Provinsi Sumatera Barat dengan FIK dalam pengembangan ilmu pengetahuan dan teknologi keolahragaan khususnya cabang bulutangkis sebagai mata kulia wajib tingkat jurusan.
\end{abstract}

Keywords: Coaching Skill,BSDM (Badminton Skill Diagnosis Model), Kinovea Software

\begin{abstract}
Related to learning and training in badminton, from field observations, several coaching clubs in West Sumatra found some basic problems, namely there are still many coaches who do not understand the nature, function and purpose and how to provide corrections to athlete's motion errors. Most of the corrections given are not based on There are still many coaches who do not understand well the analysis of motion errors and Most of the movement corrections given are based on partial trainer observations, in other words the corrections given ignore the dialogue between coaches and athletes. BSM (Badminton Skill Diagnosis Model) is a finding in evaluate using a situational approach through Diagnosis, Correction, and Therapy of motion errors that occur, which aims to: Determine the diagnosis of motion errors that occur, Correct the motion errors that occur and provide therapy for the chore action of the motion error.Kinovea is a video/visual player that has been created especially for sports professionals and coaches. Users can upload videos of those who practice different sports so that they can analyze sports movements
\end{abstract}




\section{VAHANA DEDIKASI}

and get an overview of the movements needed to be analyzed, improved and improved on the performance of these movements. coaching Skills) especially in making more accurate and targeted diagnostics, corrections and repairs to improve overall badminton playing skills. This activity will be introduced and applied to all West Sumatran badminton coaches who represent 40 people from each city district delegate and clubs that exist in conducting coaching. The implementation of the activity was carried out in the city of Padang because of the very rapid growth of the coaching club and having good facilities to carry out these activities. This activity is a collaboration with related partners, namely PBSI West Sumatra Province with FIK in the development of sports science and technology, especially the badminton branch as a compulsory subject at the department level.

Keywords: Coaching Skill,BSDM (Badminton Skill Diagnosis Model), Kinovea Software

Artikel disetujui tanggal:20-11-2021

Corresponden Author: Donie e-mail:donie17@fik.unp.ac.id

DOI: http://dx.doi.org/10.31851/dedikasi.v4i2.6702 doi

\section{PENDAHULUAN}

Banyak sekali kegagalan yang ditemui dalam belajar gerak yang disebabkan karena ketidaktepatan dalam memberikan koreksi terhadap kesalahan yang terjadi(Milanese, Cavedon, Corte, \& Agostini, 2017). Dari pengalaman di lapangan ditemui beberapa permasalahan yang cukup mendasar yaitu: Masih banyak pelatih belum memahami hakekat, fungsi dan tujuan dan cara memberikan koreksi terhadap kesalahan gerak; Kebanyakan koreksi yang diberikan belum berdasarkan diagnosa yang tepat; Masih banyak pelatih pendidikan jasmani belum memahami dengan baik penyebab terjadinya kesalahan gerakan; Kebanyakan koreksi gerakan yang diberikan berdasarkan pengamatan pelatih;
Koreksi yang diberikan mengabaikan dialog antara pelatih dan peserta didik; Banyak dari pelatih pendidikan jasmani tidak memahami secara mendasar pengertian kesalahan(Knudson, 2004)

Bulutangkis sebagai cabang olahraga yang menuntut keterapilan gerak yang komplek sangat menuntut penguasaan gerak yang harmonis dalam menyelesaikan berbagai tugas gerakan diantaranya: bergerak secara efektif dan efisien, mengembalikan pukulan lawan, melancarkan serangan ke daerah lawan dan kembali kepada filosofi dasar dari permainan bulutangkis, mematikan bola di daerah lawan (Findings, 2016). Banyaknya kombinasi keterampilan gerak dalam bulutangkis dalam menyelesaikan berbagai tugas gerak.

\section{3 | Wahana Dedikasi}




\section{V/AHANA DEDIKASI}

Namun tidak semua keterampilan gerak berjalan secara harmonis sesuai dengan tujuan yang diharapkan.

$$
\text { Berbagai faktor yang }
$$
mempengaruhi baik yang datang dari dalam maupun yang datang dari luar diri si atlet bisa menyebabkan terjadinya kesalahan gerak. Kesalahan yang dibiarkan menjadi permanen dan menjadi suatu kebiasaan akan sangat sulit dalam merubahnya (Hollingworth \& Barker, 2017). Untuk itu butuh upaya mendeteksi sedini mungkin bagaimana bisa melakukan evaluasi, diagnosa, koreksi dan terapi kesalahan keterampilan gerak pada permainan bulutangkis. Kemampuan dan keterampilan untuk bisa melakukan evaluasi secara situasional dan kompherensif menjadi sebuah keharusanyang harus dimiliki olah pelatihbulutangkis dalam meningkatkan prestasi atlet melalui perbaikan dari aspek teknik atau keterampilan.

BSDM merupakan sebuah temuan yang bisa dijadikan solusi dan pedoman dalam memberikan panduan tentang langkah langkah sistematis dalam melakukan evaluasi, diagnosa dari kesalahan gerak, koreksi dari kesalahan gerak dan melakukan terapi yang tepat dari kesalahan keterampilan gerak khususnya pada permainan bulutangkis.

\section{SOLUSI DAN TARGET}

BSDM merupakan sebuah temuan dan solusi yang dikembangkan untuk memudah kan pelatih dalam memberikan evaluasi keterampilan secara utuh sehingga bisa diberikan kriteria penilaian yang objektif dan bisa dijadikan ukuran keterampilan bermain dari atlet yang di latih. BSDM merupakan kombinasi dari pengembangan dari unsur unsur teknik bulutangkis yang meliputi, Footwork, Stroke dan koordinasi dari seluruh elemen gerak yang terlibat. BSDM di analisis dengan menggunkan aplikasi Kinovea atau video slowmotion untuk bisa menganalisis secara perlahan sesuai dengan kriteria yang ditetapkan dan bisa dilakukan pengulangan sesuai dengan kebutuhan yang ingin di dapatkan oleh si pelatih

Instrument Badminton Skills Diagnostic Model (BSDM) ini, bertujuan untuk mendiagnosis rangkaian keterampilan gerak bermain bulutangki tingkat pemula. Adapun bagian yang didiagnosa 
adalah (1) footwork, (2) Sikap

Memukul (Execution), (3) jalannya

Shnuttlecock, dan (4) Stroke

(Pukulan), secara bersamaan

dianalisis mengunakan instrument

diagnosa untuk mengetahui

keterampilan yang dimiliki

pemain/atlet dalam penguasaan teknik

bermain, seperti, smash, atau servis,

forehand dan backhand

Instrument Badminton Skills

Diagnostic Model, menghadirkan sebuah bentuk baru dalam mengdiaknosa gerak. Kerja dari instrument ini yaitu memberikan manfaat bagi:

1) Pelatih, sebagai instrument untuk melihat penguasaan keterampilan yang dimiliki pemain/atlet.

Karena dengan mengunakan instrument ini, pelatih akan mengetahui kesalahan gerak yang dimiliki atlet, dengan demikian pelatih akan dapat memberikan asessmen atu koreksi terhadap keterampilan yang dimilki pemain/atlet. Selain itu, pelaksanaan dari tes ini juga dapat dijadikan bentuk latihan untuk melakukan pemodela dalam mengembangkan keterampilan yang dimiliki pemain bulutangkis.

2) Atlet, dapat dijadikan sebagai tolak ukur untuk kinerja dari keterampilan yang dimilki. Karean keungulan mengunakan instrument ini, pemain/atlet sudah merasa berada disituasi pertandingan. Hal ini disebabkan karena jalannya shuttlecock diatur untuk melibatkan semua teknik dasar bermain bulutangkis. Oleh sebab itu instrument ini, dapat dijadikan sebagai salah satu referensi untuk mengukur kinerja dari keterampilan bermain bulutangkis.

Instrument Badminton Skills Diagnostic Model (BSDM) merupakan formula dalam mediagnosa rangkaian gerakan keterampilan bulutangkis, untuk kerja teknik yang terkoordinasi seperti: (1) footwork, (2) Sikap Memukul (Execution), (3) jalannya Shuttlecock, dan (4) Stroke (Pukulan). Implementasi dari model ini dilakukan mengunakan bantuan elektronik (kamera) untuk mengambil video dan menentukan kesesuaian 
antara gerak atlet dengan tabel indikator.

Selanjutnya mengisi hasil pengamatan dengan cara cheklist pada kolom criteria (Jelek, baik, dan baik sekali). Hasil pengukuran yang dilakukan bertujuan untuk mengkoreksi dan trapi terhadap keterampilan gerak bulutangkis yang dimiliki atlet. Kedepanya, BSDM ini akan dikembangkan kearah elektronik mengunakan sensor yang dapat menggunakan untuk membantu playsto merekam gerakan footwork, (2) Sikap Memukul (Execution), (3) jalannya Shuttlecock, dan (3) Stroke (Pukulan), dalam satu pola gerakan bermain bulutangkis yang mengunakan lapangan standar.

\section{Instrumen Badminton Skills Diagnosic Model (BSDM Model)}

\begin{tabular}{|c|c|c|c|c|}
\hline \multirow{2}{*}{ Aspek Peneliaian } & \multirow{2}{*}{ Indikator } & \multicolumn{3}{|c|}{ Kriteria Nilai } \\
\hline & & 1 & 2 & 3 \\
\hline \multirow[t]{3}{*}{ Footwork } & $\begin{array}{l}\text { - Standing Potition } \\
\text { (Sikap tubuh : togok, tangan dan kaki } \\
\text { ) saat menunggu shuttlecock) }\end{array}$ & & & \\
\hline & $\begin{array}{l}\text { Speed Footwork } \\
\text { (Kelancaran dan kecepatan dan } \\
\text { gerakan kaki) }\end{array}$ & & & \\
\hline & $\begin{array}{ll}\text { Variasi Footwork } \\
\text { (Variasi dan ketepatan Gerakan Kaki) }\end{array}$ & & & \\
\hline \multicolumn{2}{|r|}{ Jumlah } & & & \\
\hline \multirow[t]{2}{*}{$\begin{array}{l}\text { Sikap Memukul } \\
\text { (Execution) }\end{array}$} & \begin{tabular}{|l|} 
Hitting position \\
(penempatan posisi tubuh saat \\
memukul)
\end{tabular} & & & \\
\hline & $\begin{array}{l}\text { Memukul (execution) } \\
\text { (kelancaran dan ketepatan pukulan } \\
\text { (fase awal :back swing), fase utama: } \\
\text { impact dan fase akhir: foward swing } \\
\text { \&Follow through ) }\end{array}$ & & & \\
\hline \multicolumn{2}{|r|}{ Jumlah } & & & \\
\hline \multirow[t]{2}{*}{ Jalannya Shuttlecock } & $\begin{array}{ll} & \text { Speed \&Ketepatan } \\
\text { (sudut dan ketepatan cock) }\end{array}$ & & & \\
\hline & 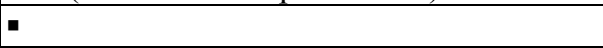 & & & \\
\hline \multirow[t]{5}{*}{ Stroke (Pukulan) } & - $\quad$ Service & & & \\
\hline & - $\quad$ Netting + Block + Drive & & & \\
\hline & - $\quad$ Underhand Lob & & & \\
\hline & - Clear/lob & & & \\
\hline & \begin{tabular}{|l|} 
- Smash/Drop Shoot \\
\end{tabular} & & & \\
\hline \multicolumn{2}{|r|}{ Jumlah } & & & \\
\hline & TOTAL & & & \\
\hline
\end{tabular}


Meningkatan "Coaching Skill" Pelatih Bulutangkis Sumatera Barat Melalui Pendekatan

BSDM (Badminton Skill Diagnosis Model) Berbasis Kinovea Software

\section{W/AHANA DEDIKASI}

\section{BAHAN DAN METODE}

\section{Kerangka Pemecahan Masalah}

Pemecahan masalah dalam kegiatan pelatihan ini terdiri dari pelatihan bagaimana mengenal Pengenalan Instrumen BSDM, Pengenalan Aplikasi Kinovea, Praktek Penggunan Instrumen serta bagaimana menuangkan instrumen tersebut ke dalam kisi kisi dan norma nilai yang sudah ditetapkan.

Adapun proses kegiatan terdiri dari penyajian materi secara teori oleh narasumber, kemudian diskusi. Selanjutnya dilakukan praktik terkait elemen dasar dari keterampilan bulutangkis yang dirangkum dalam sebuah model penilaian secara utuh. Selanjutnya bagaimana menggunakan aplikasi kinovea sebagai alat dalam menganalisis keterampilan gerak tersebut untuk antinya dituangkan kedalam kisis kisi instrumen yang sudah dirancang tersebu.

1. Realisasi Pemecahan Masalah

Sebelum kegiatan dilaksanakan, terlebih dahulu dilakukan hal-hal sebagai berikut. a. Melakukan studi pustaka tentang berbagai teori, terkait elemen dasar dari keterampilan bulutangkis, Pengenalan Dasar Dasar Evaluasi secara Umum, Pengenalan BSDM Model, Pengenalan Aplikasi Kinovea

b. Menetapkan waktu dan tempat serta lamanya kegiatan bersama tim pelaksana.

c. Menentukan dan mempersiapkan materi yang akan disampaikan dalam kegitan.

d. Mempresentasikan materi-materi pelatihan dan diselingi dengan diskusi serta Tanya jawab.

e. Pemutaran video Elemen dasar keterampilan bulutangkis yang akan di analisis

f. Praktek Penggunaan BSDM berbasiskan Kinovea

g. Evaluasi Kegiatan

Pelaksanaan Kegiatan

Kegiatan pengabdian ini dilaksanakan di Kota Padang dengan urutan kegiatan sebagai berikut:

Registrasi ulang peserta kegiatan. 
a. Acara pembukaan.

b. Pemaparan materi kegiatan, (paparan, Tanya jawab, diskusi

c. Demonstrasi oleh instruktur, kemudian diikuti oleh semua peserta, dilanjutkan dengan

d. Evaluasi tingkat pemahaman dan penggunaan penggunaan dan pemanfaatan ari BSDM yang berbasiskan Kinovea dalam kegiatan evaluasi Keterampilan bermain bulutangkis

A. Khalayak Sasaran

Khalayak sasaran dalam kegiatan ini pelatih bulutangkis yang aktif dalam melakukan pembinaan (utusan dari pengkab/Pengkot Kabupaten/Kota se Sumatera Barat) ditambah dengan pelatih bulutangkis di klub klub yang aktif melakukan pembinaan atlet potensial ( 40 orang)

B. Metode Penerapan Ipteks

Sesuai dengan tujuan yang ingin dicapai, maka metode kegiatan yang diterapkan adalah: ceramah, demontrasi, praktek dan diskusi dengan narasumber serta para panitia pelaksana.
C. Rancangan Evaluasi

Kegiatan ini dilakukan evaluasi, baik evaluasi proses maupun evaluasi hasil. Evaluasi proses dilaksanakan selama kegiatan berlangsung yang terdiri dari: disiplin, keseriusan, ketertiban dan keterlibatan. Sebaliknya, untuk evaluasi hasil berdasarkan hasil tes yang diberikan pada akhir kegiatan, baik tes teori, maupun tes praktik.

\section{PELAKSANAAN KEGIATAN}

Pelaksanaan pelatihan dilakukan selama 4 hari (8-11 Juli 2021 ) di Ruang Pertemuan Asrama haji Padang, dan untuk Praktek GOR Bulutangkis FIK UNP

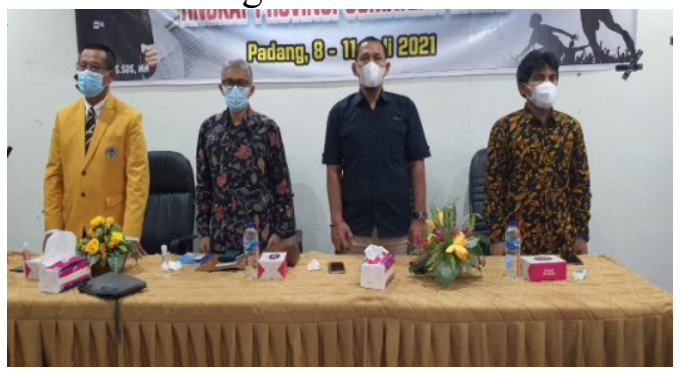

Gambar 1 : kegiatan pembukaan Pelatihan BSDM 


\section{WAHANA DEDIKASI}

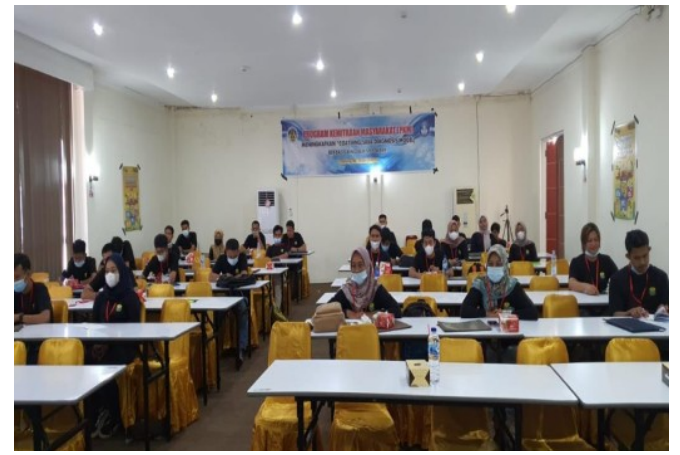

Gambar 2 : Kegiatan Teori BSDM

Berbasis Kinovea

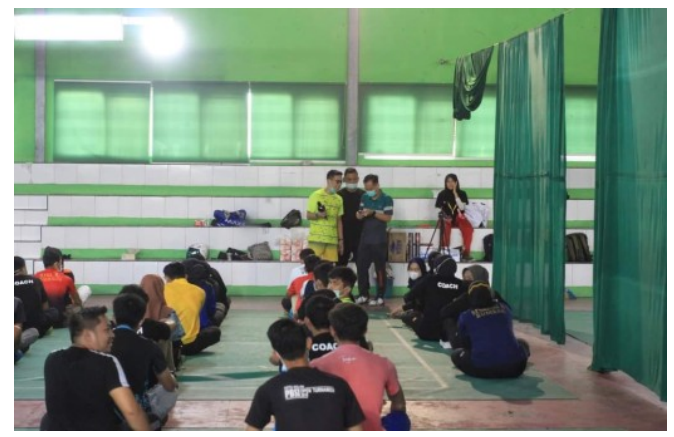

Gambar 3: Kegiatan Praktek BSDM

\section{HASIL DAN PEMBAHASAN}

Sesuai dengan target yang diharapkan pada akhir kegiatan ini adalah meningkatnya pengetahuan, kemampuan dan kererampilan pelatih bulutangkis baik pengetahuan secara teoritis terkait dengan ilmu dan aspek aspek penunjang pencapaian prestasi namun juga pelatih mendapatkan keterampilan dalam menganalisis keterampilan bermain secara utuh melalui instrument penilaian dengan format BSDM. Luaran lainnya yang diharapkan adalah lahirnya sebuah karya ilmiah yang dipublikasikan pada jurnal ilmiah maupun jurnal pengabdian. Memberikan pengalaman ril di lapangan kepada mahasiswa yang terlibat dalam kegiatan pengabdian ini, sehingga menjadi pemicu untuk melahirkanide-ide yang dapat dituangkan dalam proposal PKM atau dalam tugas akhir. Diharapkan pula hasil kegiatan ini dapat dipublikasikan pada media massa baik cetak maupun non cetak.

\section{Pembahasan}

Dalam kegiatan pengabdian ini terdapat 2 hal yang akan diberikan kepada mitra, yaitu pengetahuan serta teknologi. Dalam hal pengetahuan, mitra akan diberikan informasi tentang informasi bagaimana BSDM yang merupakan sebuah temuan dan solusi yang dikembangkan untuk memudah kan pelatih dalam memberikan evaluasi keterampilan secara utuh sehingga bisa diberikan kriteria penilaian yang objektif dan bisa dijadikan ukuran keterampilan bermain dari atlet yang di latih. 


\section{W/AHANA DEDIKASI}

Sedangkandalamhalteknologiadalah

teknologipelatih juga dibekali dengan kemampuan menggunakan aplikasi Kinovea atau video slowmotion untuk bisa menganalisis secara perlahan sesuai dengan kriteria yang ditetapkan dan bisa dilakukan pengulangan sesuai dengan kebutuhan yang ingin di dapatkan oleh si pelatih. keuntungan utama kinovea adalah kemudahan penggunaan dan analisis tanpa menggunakan sensor fisik. Selain itu,gratis dan bisa digunakan dalam pengukuran pada gerak dengan berbagai kegunaan Termasuk kecepatan kursor, dapat memilih zona kerja untuk membuat navigasi kursor lebih tepat, ermasuk pemutaran ulang layar, Mendukung perbandingan dan sinkronisasi video, alat-alat observasi yang beragam, banyak fungsi pengukuranMendukung penangkapan layar dan perekaman gambar maupun video, Kegiatan tersebut akan dirancang sedemikian rupa melalui berbagai tahapan. Untuk lebih jelasnya dapat dilihat dalam alur pelaksanaan kegiatan dibawah ini:

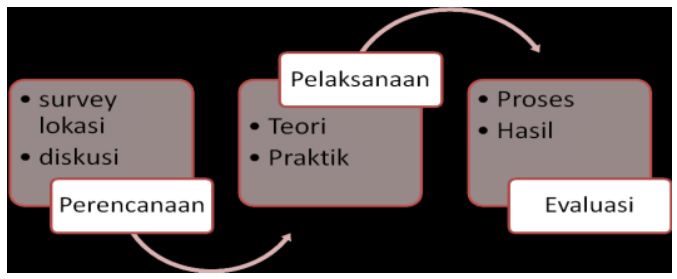

Gambar 4. Proses Pelaksanaan

KESIMPULAN

$$
\text { Upaya peningaktan }
$$

kemampuan dan keterampilan pelatih merupakan hal penting dalam upaya percepatan pencapaian prestasi. Berkembangnya teknologi keolahragaan yang sekarang dikenal dengan sport science menjadikan para pelatih harus dibekali denganpengetahuan terkini terkait dengan cabang bulutangkis serta bagaimana mengaplikasikan sport science tersebut dalam pelaaksanaan tugas dilapangan.

BSDM adalah sebuah instrument yang memiliki keunggulan dalam mengevaluasi teknik bulutangkis secara utuh, sesuai dengan situasional permainan dan secara lengkap mengakomodir unsur unsur teknik uatam adalam permaian bulutangkis, baik pegangan, pergerakan (ffotwork) dan berbagai 
jenis pukulan (stroke). Ini akan semakin penting jika pelatih juga bisa menganalisis gerakn dengan menggunakan aplikasi sederhana baik yang gratis maupu yang pro sehingga akan bisa didapatkan apakah gerak secara utuh ayapun data data yang berguna bagi pelatih sebagai informasi dalam mengambi keputusan, perbaiak ataupun peningaktan keterampial bermain atlet biaanya.

\section{UCAPAN TERIMAKASIH}

Terima kasih di sampaikan kepada PBSI Provinsi Sumatera Barat yang telah memfasilitasi proses pelatihan BSDM, dengan menyediakan tempat pelaksanaan dan mengkoordinir peserta. Terima kasih kepada Pelatihpelatih PBSI Provinsi Sumatera Barat yang terlah bersedia mengikuti kegiatan ini.

\section{DAFTAR PUSTAKA}

Findings, E. (2016). The effect of game specific training on selected badminton skills, (October), 3-6.
Komaini, A., \& Mardela, R. (2017). Fundamental Motor Skills of Kindergarten Students ( A Survey Study of the Influence of Financial Condition , Playing Activity, and Nutritional Status ) Fundamental Motor Skills of Kindergarten Students ( A Survey Study of the Influence of Financial Condi. https://doi.org/10.1088/17426596/755/1/011001

Kiram, Y. (n.d.). ( Edisi Revisi ) Universitas Negeri Padang.

Knudson, D. (2004). The Hill Muscle Model. Fundamentals of Biomechanics. https://doi.org/10.1016/S00319406(05)61176-5

Milanese, C., Cavedon, V., Corte, S., \& Agostini, T. (2017). The effects of two different correction strategies on the snatch technique in weightlifting. Journal of Sports Sciences, 35(5), 476483.

Asnaldi, A. (2019). Panduan Pelatihan Komponen Motor Ability Bagi

Pelatih Lemkari Dojo Angkasa Lanud Padang. ResearchGate. https://www.researchgate.net/publicatio n/332709190_Panduan_Pelatihan_ Komponen_Motor_Ab ility_Bagi_Pelatih_Lemkari_Dojo_Ang kasa_Lanud_Padang

Ability in the Level of Development on Control Objects of Early Childhood Education Students in 
Meningkatan "Coaching Skill" Pelatih Bulutangkis Sumatera Barat Melalui Pendekatan BSDM (Badminton Skill Diagnosis Model) Berbasis Kinovea Software

\section{WAHANA DEDIKASI}

Pariaman City and Padang Panjang City. Proceedings of the 1 st International Conference of Physical Education (ICPE 2019), 97-100. https://doi.org/10.2991/assehr.k.2008 05.028

Barnett, F., \& Thomas, Y. (2012). The impact of exercise on the mental health and quality of life of people with severe mental illness : a critical review. March 2014, 47-60. https://doi.org/10.4276/030802 212X13286281650956

BPS. (2018). No Title.

Didik Rilastiyo Budi, Arfin Deri Listiandi, Rifqi Festiawan, Neva Widanita, D. A. (2020). Indeks Masa Tubuh (IMT): Kajian Analisis Pada Atlet Renang Junior Usia Sekolah Dasar Didik. Journal of Teaching Physical Education in Elementary School, 3(2), 46-53. https://doi.org/https://doi.org/1 0.17509/tegar.v3i2.24452

Drachsler, H. (2011). Learner Characteristics. January. https://doi.org/10.1007/978-14419-1428-6

Glasow, P. (2005). Fundamentals of Survey Research Methodology.

Harackiewicz, J. M., \& Hulleman, C. S. (2010). The Importance of Interest : The Role of Achievement Goals and Task
Values in Promoting the Development of Interest. 1, 4252.

Harper, S. (2012). The Leader Coach: A Model of MultiStyle Leadership. Journal of Practical Consulting, 4(1), 22-31.

Kirca, A. H., Jayachandran, S., \& Bearden, W. (2005). Market Orientation : A Meta-Analytic Review and Assessment of Its. April. https://doi.org/10.1509/jmkg.69. 2.24.60761

Omar, D., \& Aman, M. S. (2009). Sports Facilities Development and Urban Generation. April. https://doi.org/10.3844/jssp. 2009.460.465

Osborne, R. E. (2013). Journal of Online Learning and Teaching It Can Be Taught: Explorations into Teaching the Foundations for Multicultural Effectiveness in an Online Course. December.

Papa, S. (2017). The Effects of Physical Activity on Social Interactions: The Case of Trust and Trustworthiness The Effects of Physical Activity on Social Interactions : The Case of Trust and Trustworthiness. July. https://doi.org/10.1177/1527002 517717299 
Donie, Yogi Setiawan, Eval Edmizal (2021)

Meningkatan "Coaching Skill" Pelatih Bulutangkis Sumatera Barat Melalui Pendekatan

BSDM (Badminton Skill Diagnosis Model) Berbasis Kinovea Software

\section{WAHANA DEDIKASI}

Science, I., Queen, H., \& Queen, H. (2013). Guideline adaptation and implementation planning : A prospective observational study. December 2016.

https://doi.org/10.1186/17485908-8-49

Learners 'Motivation on

Their Reading

Comprehension Skill : A

Literature Review. 10-21.

Woodward, M. (2011). SHUTTLE

TIME. BWF Journal.

Takaloo, N. M., \& Ahmadi, M.

R. (2017). The Effect of 